\title{
Phenotypic Stability for Yield and Some Quality Traits in Brassica juncea L.
}

\author{
Mohammad Jafar Tanin ${ }^{1,2}$, Ashwani Kumar ${ }^{1 *}$ and S.K. Gupta ${ }^{1}$ \\ ${ }^{1}$ Division of Plant Breeding \& Genetics, SK University of Agricultural Sciences and \\ Technology, FOA, Main campus, Chatha, Jammu-180009 (J\&K), India \\ ${ }^{2}$ Afghanistan Agricultural Input Project, Ministry of Agriculture, Irrigation and Livestock, \\ Afghanistan
}

*Corresponding author

\begin{tabular}{|c|c|c|}
\hline & \multicolumn{2}{|l|}{ A B S T R A C T } \\
\hline $\begin{array}{l}\text { Ke y w o r d s } \\
\text { Brassica juncea, } \\
\text { Indian mustard, } \\
\text { Stability analysis, } \\
\text { G×E interaction, } \\
\text { Phenotypic stability }\end{array}$ & \multirow{3}{*}{\multicolumn{2}{|c|}{$\begin{array}{l}\text { The current investigation aims to determine the phenotypic stability and GxE interaction } \\
\text { among the Brassica juncea L. genotypes. Fifteen released genotypes of Brassica juncea L. } \\
\text { were evaluated in two different environments and two dates of sowing during Rabi 2014- } \\
2015 \text { and 2015-2016. Analysis of variance indicated that all the genotypes exhibited } \\
\text { significant genetic differences except forno. of secondary branches/plant, siliqua length, } \\
1000 \text { seed weight and oil content. The mean squares due to environment were significant } \\
\text { for all the characters and GxE interactions were also observed to be significant for traits } \\
\text { viz., no. of primary branches/plant, no. of secondary branches/plant, days to } 50 \% \\
\text { flowering, days to } 100 \% \text { flowering and days to maturity. Considering high mean } \\
\text { performance, unit regression and non-significant mean square deviations, the genotypes } \\
\text { DRMRIJ-31 and Varuna are stable and suitable for high performance environment. The } \\
\text { genotype PM-21 was considered as stable and suitable for low performance environment. }\end{array}$}} \\
\hline Article Info & & \\
\hline $\begin{array}{l}\text { Accepted: } \\
\text { 07 January } 2018 \\
\text { Available Online: } \\
10 \text { February } 2018\end{array}$ & & \\
\hline \multicolumn{2}{|c|}{$\begin{array}{l}\text { Introduction } \\
\text { Rapeseed-mustard is the third important } \\
\text { oilseed crop in the world after soybean } \\
\text { (Glycine max) and palm (Elaeis guineensis } \\
\text { Jacq.) oil. Among the seven edible oilseed } \\
\text { cultivated in India, rapeseed-mustard } \\
\text { (Brassica spp.) contributes } 28.6 \text { per cent in the } \\
\text { total production of oilseeds. In India, it is the } \\
\text { second most important edible oilseed after } \\
\text { groundnut sharing } 27 \text { per cent in the India's } \\
\text { oilseed economy (Shekhawat et al., 2012). } \\
\text { World output of rapeseed and mustard has }\end{array}$} & $\begin{array}{l}\text { India is the fourth largest producer of } \\
\text { rapeseed-mustard after European Union, } \\
\text { Canada and China. Production trends over the } \\
\text { past two decades indicated that there was a } \\
\text { significant shift in production levels from } \\
\text { about } 5-6 \text { million tons until } 2002-03 \text { to around } \\
6.8 \text { million tons in 2106-2017 (USDA, May } \\
2016 \text { ). }\end{array}$ \\
\hline
\end{tabular}


Out of six species viz., Brassica rapa (AA, $\mathrm{n}=10)$; Brassica oleracea $(\mathrm{CC}, \mathrm{n}=9)$ and Brassica nigra (BB, $\mathrm{n}=8)$; Brassica juncea (AABB, $\mathrm{n}=18$ ), Brassica napus (AACC, $\mathrm{n}=19)$ and Brassica carinata $(\mathrm{BBCC}, \mathrm{n}=17)$, B. juncea or Indian mustard or raya is predominantly grown in sub-tropical area and brown sarson in intermediate zone of the Jammu province.

Environmental factors greatly affect plant growth and yield. Sowing date is an important determinant of crop yield and it depends on the onset of significant rainfall, temperature and humidity of a region. Decreasing crop yield in delayed sowing date has been reported by many workers (Kohn and Storrier 1970; Doly and Marcellos 1974; Degenhardt and Kondra 1981; McDonald et al., 1983). Therefore, yield and yield contributing traits of a crop are highly influenced by environment. Genotype-location interaction usually implies differential behavior of genotypes under different environments. The magnitude of components of genetic variation and genotype-environment interaction can help to select the promising and stable genotypes. It can also help the plant breeders to select the suitable genotypes either for specific environment or for a wide range of environments. The presence of genotypeenvironment $(\mathrm{G} \times \mathrm{E})$ interaction confounds the selection of superior genotypes by altering their relative productiveness and makes it difficult to judge the genetic potential of a genotype.

The success of a crop variety depends not only on its high performance but also on its ability to perform consistently over environments as the phenotypic performance of a genotype of often reflected by diverse agro-ecological conditions. Some genotypes may perform well in some environments but not in others. Thus, $\mathrm{G} \times \mathrm{E}$ interactions are of great significance in plant breeding as they affect stability of genotypes across environments. Under such condition, it becomes necessary to identify the stable varieties from already released varieties which could show steady performance over the years under different environments.

\section{Materials and Methods}

The experiment was undertaken during Rabi 2014-2015 and 2015-2016 at the Research Farm of Division of Plant Breeding and Genetics, Faculty of Agriculture, Sher-eKashmir University of Agriculture Sciences and Technology, Jammu (SKUAST-J), Chatha. Chatha is located at latitude of $32^{\circ} 40^{\prime}$ $\mathrm{N}$ and longitude of $78^{\circ} 48^{\prime} \mathrm{E}$ and altitude of 293 meters above mean sea level. The materials for present experiment consist of 15 recently released varieties enumerated in Table 1. All genotypes were selected on the basis of variation for yield, maturity, oil and erucic acid content. These varieties were evaluated in randomized block design with 3 replications. In each replication, each entry was sown in a plot of seven rows, each row consisting with 4 meters length, row to row distance was $30 \mathrm{~cm}$ and plant to plant distance was maintained at $10 \mathrm{~cm}$ by thinning after 20 days of sowing. The sowings were done during Rabi 2014-2015 and 2015-2016 in two different environments created by two dates of sowing, one on $23^{\text {th }}$ October (E1) and other on $7^{\text {th }}$ November (E2). A basal dose of fertilizer at rate of $80 \mathrm{Kg} \mathrm{N}, 40 \mathrm{Kg} \mathrm{P}$ and $40 \mathrm{Kg} \mathrm{K}$ was applied at the time of sowing. All the recommended cultural practices were followed for raising the crop. The multi-environmental data were subjected to stability analysis following the regression approach model of Eberhart and Russell (1966).

\section{Results and Discussion}

The joint regression analysis indicated a high genetic variability among the genotypes included in this study for all the characters. 
The magnitude of $\mathrm{G} \times \mathrm{E}$ interaction and stability parameters for various characters were estimated according to Eberhart and Russell (1966) and presented in Table 2. Scrutiny of Table 2 exhibited that the $\mathrm{G} \times \mathrm{E}$ interactions were significant for number of primary branches/plant, number of secondary branches/plant, days to 50 per cent flowering, days to 100 per cent flowering, days to maturity and oil content indicating the variable performance of genotypes for different characters in different environments. Significant $\mathrm{G} \times \mathrm{E}$ interaction for various traits have also been reported by various workers in India mustard (B. juncea L.) genotypes by Rajender Singh, (2014) and Gupta and Pratap, (2007), in Brown sarson (B. rapa L.) by Gazal et al., (2013), in Canola (B. napus L.) by Tahira et al., (2013) and in White mustard (B. Alba L.) by Abou El-Nasr et al., (2006). All of the characters were highly influenced by environments due to year to year variations as suggested by significant environmental variation for these characters. The Env. + (Geno. $\times$ Env.) Interactions were significant for all the characters except number of siliquae on main shoot and 1000-seed weight, indicating that these characters were unstable and fluctuated in their expression with change in environment. The $\mathrm{G} \times \mathrm{E}$ (linear) was significant for number of primary branches/plant, number of secondary branches/plant, seed yield/plant, days to 50 per cent flowering, days to 100 per cent flowering and days to maturity, indicating that for these characters therefore, genotypes differed from each other with respect to their linear response and prediction can be made easily. Pooled deviation was also significant for all the traits except plant height, 1000 seed weight, days to $50 \%$ and $100 \%$ flowering and days to maturity, suggesting that a substantial portion of $\mathrm{G} \times \mathrm{E}$ interaction was due to some factor other than the regression. The mean squares due to $\mathrm{G} \times \mathrm{E}$ (linear) were significantly higher in magnitude for number of primary branches/plant, number of secondary branches/plant, seed yield/plant, days to 50 per cent flowering, days to 100 per cent flowering, days to maturity and oil content as compared to the mean squares due to pooled deviation. It indicated that there was predominance of $\mathrm{G} \times \mathrm{E}$ (linear) for number of primary branches / plant, number of secondary branches/plant, seed yield/plant, days to $50 \%$ flowering, days to $100 \%$ flowering, days to maturity and oil content and prediction can be possible for these characters.

According to Eberhart and Russell (1966), the regression of the variety mean on environmental index and function of the squared deviations from this regression would provide estimate of the desired stability parameters. The term stable variety has been used for a variety that performs above average in all environments. Hence, the stable variety has high mean $(\overline{\mathrm{X}} i)$, unit regression $\left(\mathrm{b}_{\mathrm{i}}=1\right)$ and the deviation from regression as small as possible $\left(S^{2} d_{i}=0\right)$. Genotypes with lowest or non-significant mean square deviation being most stable and vice-versa. The three parameters $\overline{\mathrm{X}}, \mathrm{b}_{\mathrm{i}}$ and $\mathrm{S}^{2} \mathrm{~d}_{\mathrm{i}}$ together gave an idea of adaptability of genotypes across the environments. The data related to stability parameters are presented in Table 3. Regression co-efficient (growth response index) measures response to increment in an improving environment. Genotypes with values of $b_{i}$ greater than one $\left(b_{i}>1\right)$ were described as better performance in better environment, whereas genotypes with values of $b_{i}$ less than one $\left(b_{i}<1\right)$ were described as better performance in less environment showing above average responsiveness and $b_{i}$ value equal to one $\left(b_{i}=1\right)$ described as most stable. But also, Lerner (1954), first time suggested a simple measure of phenotypic stability which is termed stability factor (S. F.) and later on the term stability was originally used by Finlay and Wilkinson (1963) to refer to the slopes of the regression lines. 
Table.1 Genotypes, pedigree and their distinguishing feature

\begin{tabular}{|c|c|c|c|}
\hline S. No. & Genotypes & Pedigree & Distinguishing Features \\
\hline 1 & PM-21 & Pusa bold $\times$ ZEM 2 & $\begin{array}{l}\text { High yielding and contains low erucic acid } \\
\text { and low glucosinulate content. }\end{array}$ \\
\hline 2 & RSPR-03 & Kranti $\times$ Pusa bold & $\begin{array}{l}\text { Contains oil content of } 40 \% \text { and matures in } \\
145 \text { days with average yield of } 15 \mathrm{q} / \mathrm{ha} \text {. }\end{array}$ \\
\hline 3 & Kranti & Selection from varuna & $\begin{array}{l}\text { Contains oil content of } 40 \% \text { and matures in } \\
125-130 \text { days with average yield of } 15-18 \\
\text { q/ha. This variety is tolerant to Alternaria } \\
\text { blight than varuna and more resistant to } \\
\text { downy mildew. }\end{array}$ \\
\hline 4 & RSPR-69 & RLM $-198 \times$ Varuna & High yielding and contains $42 \%$ oil content. \\
\hline 5 & PusaTarak & $\begin{array}{l}\text { Agra local } \times \text { Poorbi } \\
\text { Raya }\end{array}$ & $\begin{array}{l}\text { High yielding contains } 40 \% \text { oil content and } \\
\text { matures in } 130-135 \text { days. }\end{array}$ \\
\hline 6 & RL-1359 & RLM $-514 \times$ Varuna & $\begin{array}{l}\text { Tolerant to aphid and has oil content of } 43 \% \\
\text { with average yield of } 19-21 \mathrm{q} / \mathrm{ha} \text {. }\end{array}$ \\
\hline 7 & CS-56 & ZH851 × Pusa Bold & $\begin{array}{l}\text { Suitable for late sown condition and salinity } \\
\text { condition. }\end{array}$ \\
\hline 8 & Nov Gold & Bio-902 × BM-185-11 & $\begin{array}{l}\text { High yielding with perfused branching } \\
\text { contains } 42 \% \text { oil content. }\end{array}$ \\
\hline 9 & NRCDR-2 & $\begin{array}{l}\text { MDOC- } 43 \times \text { NBPGR- } \\
36\end{array}$ & $\begin{array}{l}\text { High yielding variety with seed size of } 5-5.8 \\
\text { g. It contains } 40.2 \% \text { oil and matures in } 141 \\
\text { days with average yield of } 16.69 \mathrm{q} / \mathrm{h} \text {. }\end{array}$ \\
\hline 10 & $\begin{array}{l}\text { DRMRIJ- } \\
\quad 31\end{array}$ & & $\begin{array}{l}\text { High yielding variety with seed size of } 5-5.8 \\
\text { g. It contains } 40.2 \% \text { oil and matures in } 143 \\
\text { days. Its average yield is } 17.5 \mathrm{q} / \mathrm{ha} \text {. }\end{array}$ \\
\hline 11 & Urvash & Varuna $\times$ Kranti & High yielding and matures in 140 days. \\
\hline 12 & RSPR-01 & $\begin{array}{l}\text { Brassica juncea } \times \\
\text { Diplotaxixmuralis }\end{array}$ & $\begin{array}{l}\text { It is high yielding with oil content of } 40 \% \\
\text { and the average yield is } 19-20 \mathrm{q} / \mathrm{h} \text {. }\end{array}$ \\
\hline 13 & Pusa Bold & Varuna $\times$ BIC 1780 & $\begin{array}{l}\text { High yielding with seed size of } 6.0-7.0 \mathrm{~g} \text {, It } \\
\text { contains oil content of } 42 \% \text {. }\end{array}$ \\
\hline 14 & Varuna & $\begin{array}{l}\text { Pure selection from } \\
\text { varansi local }\end{array}$ & $\begin{array}{l}\text { It is high yielding variety with seed size of 5- } \\
6.5 \mathrm{~g} \text {. Its average yield is } 20-22 \mathrm{q} / \mathrm{ha} \text {. }\end{array}$ \\
\hline 15 & RB-55 & $\begin{array}{l}\text { Selection from RB- } \\
2001\end{array}$ & $\begin{array}{l}\text { High yielding and suitable for rain fed } \\
\text { condition. }\end{array}$ \\
\hline
\end{tabular}


Table.2 Joint regression analysis for seed yield and its components following Eberhart and Russell (1966)

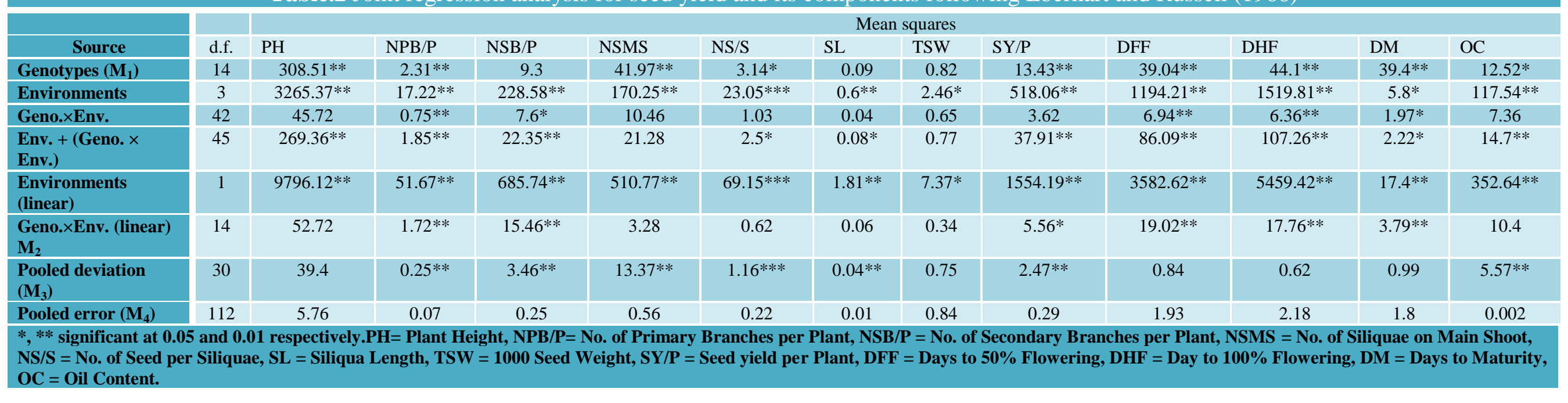

Table.3 Stability parameters $\left(\overline{\mathbf{x}}, b_{i}, S^{2} d_{i}\right)$ for seed yield and its component traits in B. juncea $\mathrm{L}$.

\begin{tabular}{|c|c|c|c|c|c|c|c|c|c|c|c|c|c|c|c|}
\hline \multirow[t]{2}{*}{ Genotypes } & \multicolumn{3}{|c|}{ No. of seeds / siliqua } & \multicolumn{3}{|c|}{ No. of siliquae on main shoot } & \multicolumn{3}{|c|}{ 1000- seed weight (gm) } & \multicolumn{3}{|c|}{ Yield / plant (gm) } & \multicolumn{3}{|c|}{ Oil content $(\%)$} \\
\hline & $\overline{\mathbf{X}}$ & $\mathbf{b}_{\mathbf{i}}$ & $\mathbf{S}^{2} \mathbf{d}_{\mathrm{i}}$ & $\overline{\mathbf{X}}$ & $\mathbf{b}_{\mathbf{i}}$ & $\mathbf{S}^{2} \mathbf{d}_{\mathrm{i}}$ & $\overline{\mathrm{X}}$ & $\mathbf{b}_{\mathbf{i}}$ & $\mathbf{S}^{2} \mathbf{d}_{\mathrm{i}}$ & $\overline{\mathrm{X}}$ & $\mathbf{b}_{\mathbf{i}}$ & $\mathbf{S}^{2} \mathbf{d}_{\mathrm{i}}$ & $\overline{\mathrm{X}}$ & $\mathbf{b}_{\mathrm{i}}$ & $\mathbf{S}^{2} \mathbf{d}_{\mathrm{i}}$ \\
\hline PM-21 & 13.27 & 0.72 & $2.78 * *$ & 42.98 & 1.46 & -0.52 & 3.85 & 0.91 & -0.77 & 14.04 & 0.8 & -0.04 & 34.03 & $0.71^{*}$ & $0.06 * *$ \\
\hline RSPR-03 & 14.67 & 0.97 & -0.1 & 36.68 & 0.72 & $3.68^{*}$ & 3.51 & 1.21 & -0.71 & 14.66 & 0.9 & $8.65^{* *}$ & 34.66 & 0.77 & $16.58 * *$ \\
\hline Kranti & 13.44 & 1.51 & 0.68 & 40.12 & 1.12 & -0.37 & 3.31 & 0.38 & -0.71 & 14.94 & 1.32 & $2.74 * *$ & 39.79 & -0.38 & $7.71 * *$ \\
\hline RSPR-69 & 12.82 & 0.82 & 0.11 & 44.15 & $1.21 *$ & -0.98 & 3.84 & 0.72 & -0.71 & 10.91 & $0.74 * *$ & -0.28 & 36.18 & 1.04 & $0.08 * *$ \\
\hline PusaTarak & 14.71 & 1.33 & $1.83^{* *}$ & 36.52 & 1.23 & $136.36^{* * *}$ & 4.28 & 2.61 & $1.81^{*}$ & 12.18 & 0.81 & $1.45^{* *}$ & 33.46 & $1.91^{* * *}$ & $0.02 * *$ \\
\hline RL-1359 & 12.27 & 1.17 & 0.12 & 43.6 & 1.35 & 1.26 & 3.27 & 0.69 & -0.76 & 15.27 & 1.15 & $1.53 * *$ & 35.95 & 0.82 & $1.19 * *$ \\
\hline CS-56 & 12.5 & 0.97 & 0.03 & 37.12 & 0.47 & $17.29 * *$ & 3.73 & 0.32 & -0.76 & 13.14 & 0.82 & 0.62 & 35.31 & 0.62 & $0.89 * *$ \\
\hline Nov Gold & 11.86 & 1.26 & 0.6 & 41.03 & 1.12 & $11.02 * *$ & 4.11 & 1.11 & -0.66 & 15.22 & 1.31 & $1.13^{*}$ & 33.35 & 1.66 & $2.72 * *$ \\
\hline NRCDR-2 & 13.07 & 1.46 & -0.13 & 38.12 & 0.88 & -0.77 & 3.43 & 0.16 & -0.78 & 15.33 & 1.07 & $2.28 * *$ & 34.78 & 1.48 & $7.13 * *$ \\
\hline DRMRIJ-31 & 12.73 & 0.56 & $2.64 * *$ & 38.55 & 0.46 & $8.97 * *$ & 3.75 & 0.82 & -0.76 & 16.49 & $1.3^{*}$ & -0.07 & 36.02 & 0.72 & $1.38 * *$ \\
\hline Urvashi & 13.72 & 1.03 & -0.18 & 41.83 & 1.06 & 0.88 & 4.03 & 0.86 & -0.69 & 10.79 & 0.79 & $0.77^{*}$ & 37.57 & 0.53 & $18.64 * *$ \\
\hline RSPR-01 & 13.55 & 1.02 & 0.1 & 46.4 & $1.38^{*}$ & -0.81 & 3.52 & 0.94 & -0.79 & 12.99 & 0.75 & $6.17 * *$ & 36.45 & 1.52 & $0.57 * *$ \\
\hline Pusa Bold & 11.92 & 0.39 & $1.06^{*}$ & 39.77 & 0.87 & 0.95 & 4.99 & 2.99 & $6.84 * *$ & 14.11 & 1.15 & $5.96 * *$ & 33.66 & 2.25 & $4.69 * *$ \\
\hline Varuna & 14.11 & 1.4 & $1.33^{*}$ & 36.28 & 0.81 & $4.06 * *$ & 3.48 & 1.33 & -0.73 & 16.41 & 1.29 & 0.27 & 35.45 & 0.71 & $0.79 * *$ \\
\hline RB-55 & 13.46 & 0.39 & 0.79 & 36.62 & 0.83 & $3.81 *$ & 3.41 & -0.06 & -0.72 & 11.98 & 0.82 & $0.96^{*}$ & 37.49 & 0.46 & $21.02 * *$ \\
\hline General Mean = & 13.21 & & & 39.98 & & & 3.77 & & & 13.9 & & & 35.61 & & \\
\hline S.E.m = & 0.62 & & & 2.11 & & & 0.5 & & & 0.91 & & & 1.36 & & \\
\hline
\end{tabular}


Genotypes with most gentle slopes being referred as most stable in contrast to the genotypes having the steepest slopes which were the least-stable. In (1958), Lerner has also reported that building in stability (development of homeostasis) appears to be a different question. However, various reports indicated that the stability to some extent is under the genetic control (Williams, 1960; Perkins and Jinks, 1986b; Ramanujam and Gupta, 1973). According to these three parameters, three genotypes Varuna, PM-21 and DRMRIJ-31 exhibited stability for seed yield. The genotype PM-21 recorded significantly higher seed yield (14.04 g) in comparison to the mean seed yield over all the genotypes $(13.9 \mathrm{~g})$, regression coefficient (0.8) and non-significant deviation from regression $S^{2} d_{i}$. This genotype was superior and suited for low performance environment and hence proved its potential to be released for commercial cultivation in the region. The genotype Varuna had higher seed yield (16.41 g), regression coefficient (1.29) and nonsignificant deviation from regression $S^{2} d_{i}$.This genotype was superior and suited for high performance environment. Also, the genotype DRMRIJ-31 exhibited higher seed yield $(16.49 \mathrm{~g})$, regression coefficient (1.3) and non-significant deviation from regression $S^{2} d_{i}$. This variety was superior and suited for high performance environment.

Critical examination of Table 3 showed that one genotype CS-56 was found stable for plant height as it exhibited high mean performance, unit regression coefficient and non-significant deviation from regression. Two genotypes CS-56 and Nov Gold were stable for number of primary branches/plant. None of the genotypes was stable for number of secondary branches/plant and siliqua length. Stable genotypes for number of siliquae on main shoot were Urvashi and Kranti. Three genotypes Urvahsi, RSPR-03 and RSPR-01 were stable for number of seeds/siliqua and two genotypes Nov Gold and PM-21 were stable for 1000-seed weight. None of genotypes was stable siliqua length. Three genotypes Varuna, PM-21 and DRMRIJ-31 exhibited stability for seed yield/plant. The genotype DRMRIJ-31, Nov Gold and PM-21 were stable for days to 50 per cent flowering. Three genotypes RSPR03, RL-1359 and DRMRIJ-31were stable for days to 100 per cent flowering, none of genotypes was stable for days to maturity and oil content. In seed yield/plant, the genotypes Kranti was found most responsive as whereas RSPR-69 was least responsive to the different environments.

\section{References}

Abou El-Nasr, T. H. S., Ibrahim, M. M. and Aboud, K. A. 2006. Stability parameters in yield of white Mustard (Brassica alba L.) in different environments. World J. Agric. Sci., 2(1): 47-55.

Anonymous, 2016.United States Department of Agriculture.

Degenhardt, D. F. and Kondra, Z. P. 1981. The influence of seeding date and seeding rate on seed yield and yield components of five genotypes of Brassica napus. Can. J. Plant Sci., 61: 175-183.

Doly, A. D. and Marcellos, H. 1974. Time of sowing and wheat yield in northern New South Wales. Aust. J. Exp. Agric. Anim. Husb., 14: 93-102.

Eberhart, S. A. and Russell, W. L. 1966. Stability parameters for comparing varieties. Crop Sci., 6: 36-40.

Finlay, K. W. and Wilkinson, G. N. 1963. The analysis of adaptation in a plant breeding programme. Aust. J. Agric. Res., 14: 742-754.

Gazal, A., Dar, Z. A., Zafar, G. and Habib, M. 2013. Stability analysis for yield and its contributing traits in Brown sarson (Brassica rapa L.) under Kashmir 
conditions in India. J. Oilseed Brassica, 4(1): 33-38.

Gupta, S. K. and Pratap, A. 2007. Phenotypic stability of Indian mustard (Brassica juncea) genotypes developed from intervarietal and intergeneric crosses. Indian J. Crop Science, 2(2): 379-382.

Kohn, G. D. and Storrier, R. R. 1970. Time of sowing and wheat production in Southern New South Wales. Aust. J. Exp. Agric. Anim. Husb., 10: 604-609.

Lerner, I. M. 1954. Genetic Homoeostasis. John Wiley and Sons. Inc. New York.

Lerner, I. M. 1958. The genetic basis of selection. John Wiley and Sons. Inc. New York.

McDonald, G. K., Sutton, B. G. and Ellison, F. W. 1983. The effect of time of sowing on the grain yield of irrigated wheat in the Namoi Valley, New South
Wales. Aust. J. Exp. Agric. Anim. Husb., 34: 229-240.

Perkins, J. M. and Jinks, J. L. 1968. Environmental and genotype $\times$ environment components of variability. VI. Diallel set of crosses. Heredity, 23: 339-356.

Ramanujam, S. and Gupta, V. P. 1973. Stability of yield and its components in bangal gram. Abstract, SABRAO. Second Genetic congress, 167.

Tahira, A, R., Ahmad Khan, M. and Amjad, M. 2013. Stability analysis of canola (Brassica napus) genotypes in Pakistan. Glo. Adv. Res. J. Agric. Sci., 2(10): 270275.

Williams, W. 1960. Relative variability of inbred lines and F1 hybrids in Lycopersicum esculentum. Genetics, 45: 1457-1465.

\section{How to cite this article:}

Mohammad Jafar Tanin, Ashwani Kumar and Gupta, S.K. 2018. Phenotypic Stability for Yield and Some Quality Traits in Brassica juncea L. Int.J.Curr.Microbiol.App.Sci. 7(02): 479-485. doi: https://doi.org/10.20546/ijcmas.2018.702.060 